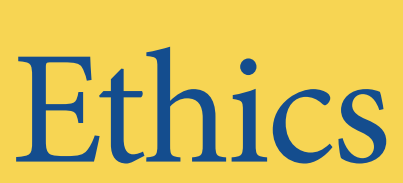

International

Affairs

VOLUME 34 . NUMBER 2 • SUMMER 2020

\title{
ROUNDTABLE: The Ethics of Limited Strikes
}

Daniel R. Brunstetter, Eric A. Heinze, Danielle L. Lupton, Rhiannon Neilsen, Wendy Pearlman, Jean-Baptiste Jeangène Vilmer

\section{ES SAYS}

From Sustainable Development Goals to Basic Development Goals

Kenneth A. Reinert

The Myth of the "Civilization State": Rising Powers and the Cultural Challenge to World Order Amitav Acharya

\section{$\mathrm{REVIEW}$ ES SAYS} COUNCII for Ethics in

for Ethics in
International Affairs
Lengthening the Shadow of International Law

Tanisha M. Fazal

A Problem from Washington: Samantha Power Enters the Foreign Policy Bureaucracy

Michael Barnett

\section{R E VIE}

The Morality of Security:

A Theory of Just

Securitization

Rita Floyd

Review by Matt McDonald

Dwelling in the Age of Climate Change: The Ethics of Adaptation

Elaine Kelly

ReVIEW By Byron WiLLISTON 


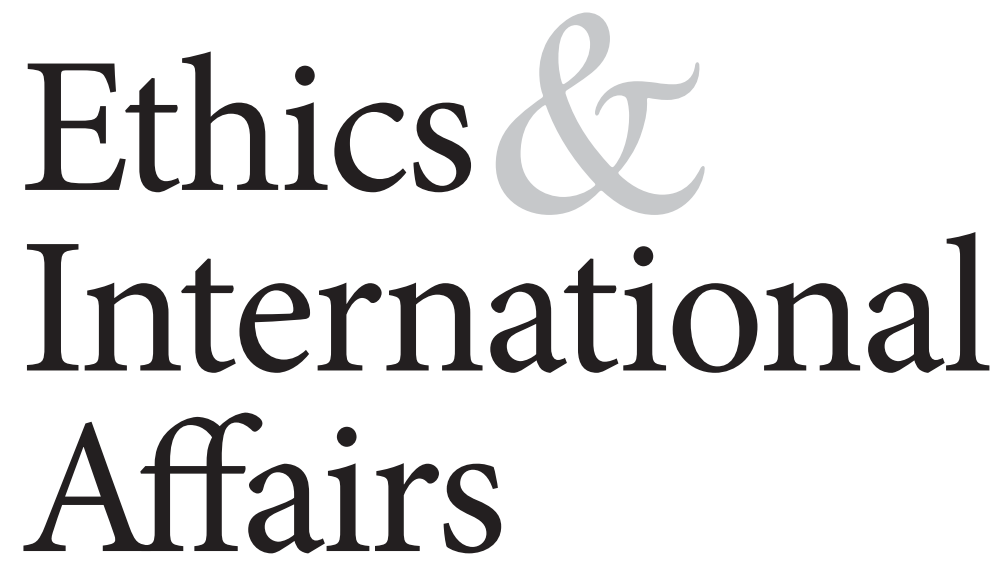

VOLUME $34 \cdot$ NUMBER $2 \cdot$ SUMMER 2020 


\section{Ethics \& International Affairs}

THE JOURNAL OF THE CARNEGIE COUNCIL

EDITOR IN CHIEF Joel H. Rosenthal

EDITOR Adam Read-Brown

ASSISTANT EDITOR Priya Chokshi

GUEST EDITOR Daniel R. Brunstetter

EDITORIAL INTERN Sonya Bandouil

COPY EDITOR Jana Weinstein

EDITORIAL ADVISORY BOARD

Christian Barry

Alex J. Bellamy

Daniel Brunstetter

Allen Buchanan

Deen K. Chatterjee

Robyn Eckersley

Toni Erskine

\section{Joy Gordon}

Nikolas Gvosdev

Ian Hurd

Anthony F. Lang, Jr.

David Luban

Darrel Moellendorf

Valerie Morkevičius
David Rodin

Jennifer Rubenstein

Henry Shue

Anna Stilz

Jennifer Welsh

Leif Wenar

\section{Carnegie Council for Ethics in International Affairs}

The Carnegie Council for Ethics in International Affairs is an independent, nonpartisan, nonsectarian, tax-exempt organization founded in 1914 by Andrew Carnegie. Since its beginnings, the Carnegie Council has asserted its strong belief that ethics, as informed by the world's principal moral and religious traditions, is an inevitable and integral component of all policy decisions, whether in the realm of economics, politics, or national security. The interrelationship of ethics and foreign policy is thus the unifying theme of all Carnegie Council programs. By promoting a greater understanding of the values and conditions that ensure peaceful relations among nations, the Carnegie Council hopes to contribute to a better life for people everywhere.

BOARD OF TRUSTEES

Maxmillian Angerholzer III

Kathleen Cheek-Milby

Aine Donovan

Richard A. Edlin

Anthony L. Faillace,

Vice Chairman

Jonathan Gage
Stephen D. Hibbard, Chairman

Haris Hromic, Treasurer

Kristen Edgreen Kaufman

Susan King

Brian Mateo

Robert Perlman
Alexander H. Platt

Joel H. Rosenthal,

President

Ronnie Saha

Robert G. Shaw,

Secretary

HONORARY TRUSTEE Maurice S. Spanbock, Esq. 


\title{
Contents
}

\author{
Contributors 121
}

ESSAYS From Sustainable Development Goals to Basic Development Goals Kenneth A. Reinert 125

The Myth of the "Civilization State": Rising Powers and the Cultural Challenge to World Order

Amitav Acharya 139

ROUNDTABLE: Introduction: The Ethical, Legal, and Strategic Implications of

THE ETHICS OF Limited Strikes

LIMITED STRIKES Daniel R. Brunstetter 157

Wading Knee-Deep into the Rubicon: Escalation and the Morality of Limited Strikes

Daniel R. Brunstetter 161

Limited Force and the Return of Reprisals in the Law of Armed Conflict

Eric A. Heinze and Rhiannon Neilsen 175

Syrian Views on Obama's Red Line: The Ethical Case for Strikes against Assad

Wendy Pearlman 189

A Matter of Balance: A French Perspective on Limited Strikes Jean-Baptiste Jeangène Vilmer 201

The Reputational Costs and Ethical Implications of Coercive Limited Air Strikes: The Fallacy of the Middle-Ground Approach Danielle L. Lupton 217

REVIEW ESSAYS Lengthening the Shadow of International Law Tanisha M. Fazal 229

A Problem from Washington: Samantha Power Enters the Foreign Policy Bureaucracy

Michael Barnett 241

REVIEWS The Morality of Security: A Theory of Just Securitization

Rita Floyd

Review by Matt McDonald 255 
Dwelling in the Age of Climate Change: The Ethics of Adaptation Elaine Kelly

Review by Byron Williston 257

SUBMISSIONS Guidelines for Submission 261

RESOURCES For additional Carnegie Council resources on the topics addressed in these pages, please visit www.eiajournal.org. 
ETHICS \& INTERNATIONAL AFFAIRS (ISSN 0892-6794 print; ISSN 1747-7093 online).

\section{Publisher}

Ethics \& International Affairs is published quarterly by Cambridge University Press, One Liberty Plaza, 2oth floor, New York, NY 10006.

\section{Information for subscribers}

Ethics \& International Affairs is published four times per year, in March, June, September, and December, by Cambridge University Press, One Liberty Plaza, 2oth floor, New York, NY 10006. Periodicals postage rate paid at New York, NY, and at additional mailing offices. POSTMASTER: Send address changes in the USA, Canada, and Mexico to: Ethics \& International Affairs, Cambridge University Press, Journals Fulfillment Department, One Liberty Plaza, 2oth floor, New York, NY 10006. Send address changes elsewhere to Ethics \& International Affairs, Cambridge University Press, Journals Fulfillment Department, UPH, Shaftesbury Road, Cambridge $\mathrm{CB}_{2}$ 8BS, England. Institutional subscription prices for 2019 are: Print \& Online: US $\$ 620$ in the USA, Canada, and Mexico; UK $\mathfrak{E}_{3} 81+$ VAT elsewhere. Institutions electronic only: US\$554 in the USA, Canada, and Mexico; UK£ $338+$ VAT elsewhere. Individuals print only: US $\$ 48$ in the USA, Canada, and Mexico; UK£ 32 + VAT elsewhere. The price includes online access to the current and all online back files to January 1st 1997, where available.

\section{Delivery Terms and Legal Title}

Prices include delivery of print journals to the recipient's address. Delivery terms are Delivered Duty Unpaid (DDU); the recipient is responsible for paying any import duty or taxes. Legal title passes to the customer on despatch by our distributors.

Production Editor: Katrina Swartz (email: kswartz@cambridge.org).

Electronic Access Access to this journal is available free online within institutions in the developing world through the AGORA initiative with the FAO, the HINARI initiative with the WHO and the OARE initiative with UNEP. For information, visit www.aginternetwork.org, www.healthinternetwork.org, www.oarescience.org. Abstracting and Indexing Services The Journal is indexed by Academic Search (EBSCO), Academic Search Premier (EBSCO), CSA Environmental Sciences \& Pollution Management Database (CSA/CIG), CSA Sustainability Science Abstracts (CSA/CIG), Current Abstracts (EBSCO), Current Contents $\%$ Social and Behavioral Sciences (Thomson Reuters), Expanded Academic ASAP (Thomson Gale), IBSS: International Bibliography of the Social Sciences (LSE), InfoTrac, International Political Science Abstracts (IPSA), Journal Citation Reports/ Social Sciences Edition (Thomson Reuters), OMNIFILE Full Text Mega Edition (OMNIFILE), PAIS: Public Affairs Information Service (CSA/CIG), Proquest 5000 (ProQuest), Proquest Discovery (ProQuest), Proquest Platinum (ProQuest), Proquest Research Library (ProQuest), Proquest Social Science Journals (ProQuest), Social Sciences Citation Index ${ }^{\infty}$ (Thomson Reuters), Social Sciences Index/Abstracts (HW Wilson), Student Resource Center College (w/ Academic ASAP),Wilson OMNIFILE Full Text Select (HW Wilson) and Worldwide Political Sciences Abstracts (CSA/CIG).

Disclaimer The Publisher, Carnegie Council, and Editors cannot be held responsible for errors or any consequences arising from the use of information contained in this journal; the views and opinions expressed do not necessarily reflect those of the Publisher, Council and Editors, neither does the publication of advertisements constitute any endorsement by the Publisher, Council and Editors of the products advertised.

Copyright and Photocopying Copyright (C) 2020 Carnegie Council for Ethics in International Affairs. All rights reserved. No part of this publication may be reproduced, in any form or by any means, electronic, photocopying, or otherwise, without permission in writing from Cambridge University Press. Policies, request forms, and contacts are available at: http://www.cambridge.org/rights/permissions/permission.htm Permission to copy (for users in the U.S.A.) is available from Copyright Clearance Center, http://www.copyright.com, email: info@copyright.com.

Printed in USA by The Sheridan Press.

View this journal online at journals.cambridge.org/EIA.

ISSN 0892-6794 (Print)

ISSN 1747-7093 (Online) 


\section{Ethics \& International Affairs}

